\title{
Renal tubular function of workers exposed to low levels of cadmium
}

\author{
K S CHIA,' C N ONG,' H Y ONG,' G ENDO'
}

From the Department of Community, Occupational, and Family Medicine, ${ }^{1}$ National University of Singapore, Singapore 0511, Republic of Singapore, and Department of Preventive Medicine, ${ }^{2}$ Osaka City University, Osaka, Japan

\begin{abstract}
Cadmium induced renal tubular effects were examined in 65 female workers in a factory manufacturing nickel cadmium batteries. Urinary $\beta 2$-microglobulin $(\beta 2 \mathrm{~m})$, urinary $\mathrm{N}$-acetyl-Dglucosaminidase activity (NAG), and serum creatinine and serum urea concentrations were used to assess the renal effects. Of the four measures, only urinary NAG and urinary $\beta 2 \mathrm{~m}$ showed a strong positive correlation with blood cadmium concentrations $(r=0.49$ and 0.43 respectively); NAG showed a weaker correlation with urinary cadmium concentrations $(r=0 \cdot 35)$. Urinary $\beta 2 \mathrm{~m}$ has weak correlation with urinary cadmium $(r=0.04)$. Only urinary NAG showed a significant deterioration in renal function among the exposed group. NAG detects the largest proportion of abnormalities among the exposed group. Abnormal urinary $\beta 2 \mathrm{~m}$ is detected in only $15.4 \%$ of the workers, half of whom have blood cadmium above $10 \mu \mathrm{g} / \mathrm{l}$. The proportion of abnormalities detected by urinary NAG differs significantly from the proportion of abnormalities detected by urinary $\beta 2 \mathrm{~m}(\mathrm{p}<0.01)$. The age adjusted mean urinary NAG excretion showed a significant rise with urinary cadmium of above $3 \mu \mathrm{g} / \mathrm{g}$ creatinine. Urinary $\beta 2 \mathrm{~m}$ failed to show any significant rise. With blood cadmium concentrations, the age adjusted mean urinary NAG excretion showed a rise from $1 \mu \mathrm{g} / 1$ of blood cadmium followed by a plateau between blood cadmium concentrations of 3-10 $\mu \mathrm{g} / 1$. No significant rise in mean urinary excretion in $\beta 2 \mathrm{~m}$ was seen until blood cadmium concentrations exceeded $10 \mu \mathrm{g} / \mathrm{l}$.
\end{abstract}

Many studies have described evidence of tubular damage or dysfunction among workers exposed to cadmium. The most typical finding is increased urinary excretion of low molecular weight proteins such as $\beta 2$-microglobulin $(\beta 2 \mathrm{~m}) \cdot{ }^{1-7}$ In tubular dysfunction the activity of urinary enzymes is also increased, especially those such as $\mathrm{N}$-acetyl-D-glucosaminidase (NAG) ${ }^{8}$ that have high specific activity in the tubules. Recently NAG has been shown to be a sensitive indicator of renal damage after occupational exposure to heavy metals ${ }^{9-13}$ and is seen as having considerable potential for screening workers engaged in handling nephrotoxic chemicals. $^{8}$

The aim of the present study was to compare the use of urinary NAG activity with other measures of renal function.

\section{Materials and methods}

\section{SUBJECTS}

Sixty five female production workers from a nickel cadmium battery factory were examined; they had been working at the factory for between one and 14 years (mean 3.7 years). Only those who fulfilled the following criteria were selected for the study:

(a) no past history of renal disease, hypertension, or diabetes mellitus;

(b) no family history of renal disease, hypertension, or diabetes mellitus;

(c) no evidence of haematuria on clinistix examination;

(d) systolic blood pressure of less than $140 \mathrm{~mm} \mathrm{Hg}$ and diastolic blood pressure below $90 \mathrm{~mm} \mathrm{Hg}$;

(e) non-smoker; and

(f) not pregnant.

Nine sedentary female office staff with no history of exposure to cadmium formed the non-exposed group. 
Table 1 General characteristics of study population

\begin{tabular}{lcc}
\hline & $\begin{array}{l}\text { Exposed } \\
\text { group } \\
(n=65)\end{array}$ & $\begin{array}{l}\text { Non-exposed } \\
\text { group } \\
(n=9)\end{array}$ \\
\hline Age distribution (years): & $2(3 \cdot 1)$ & 0 \\
$<20$ & $18(27 \cdot 7)$ & $1(11 \cdot 1)$ \\
$20-29$ & $26(40 \cdot 0)$ & $8(88 \cdot 9)$ \\
$30-39$ & $16(24 \cdot 6)$ & 0 \\
$40-49$ & $3(4 \cdot 6)$ & 0 \\
$\geqslant 50$ & $34 \cdot 6$ & $32 \cdot 7$ \\
Mean & $8 \cdot 8$ & $5 \cdot 5$ \\
SD & & \\
Racial distribution: & $18(27 \cdot 7)$ & $7(77 \cdot 8)$ \\
Chinese & $38(58 \cdot 5)$ & $2(22 \cdot 2)$ \\
Malays & $9(13 \cdot 8)$ & 0 \\
Indians & & \\
\hline
\end{tabular}

They were selected using the same criteria as the exposed group.

\section{BIOLOGICAL MEASUREMENTS}

Blood sample was obtained by venepuncture using cadmium free disposable syringes. An early morning urine sample was collected and adjusted to $\mathrm{pH} 7$ to avoid degradation of $\beta 2 \mathrm{~m} .{ }^{14}$ Samples were collected and stored in cadmium free tubes.

The following analyses were made:

(i) blood

(ii) urinary

(iii) urinary

(iv) urinary

(v) urinary

(vi) serum

(vii) serum

$\underset{\text { NAG }}{\beta 2 \mathrm{~m}}$
creatinine;

cadmium; cadmium; activity; concentration; creatinine; and urea.

Blood and urinary cadmium concentrations were assayed using a graphite atomic aborption spectrophotometer. External quality control was carried out under the National External Quality Assessment Scheme (NEQAS) in the United Kingdom and the Interlaboratory Comparison Programme of Centre de Toxicologie du Quebec in Canada. Urinary $\beta 2 \mathrm{~m}$ concentration was assayed using an enzyme immunoassay test kit (Phadezym beta2-micro test); the estimation of urinary NAG activity was performed by the method of Noto et al. ${ }^{15}$

The urinary measurements were all corrected with the urinary creatinine concentration and expressed per
Table 2 Blood and urinary cadmium concentrations of study population

\begin{tabular}{|c|c|c|}
\hline & $\begin{array}{l}\text { Exposed } \\
\text { group }\end{array}$ & $\begin{array}{l}\text { Non-exposed } \\
\text { group }\end{array}$ \\
\hline $\begin{array}{l}\text { Blood cadmium }(\mu \mathrm{g} / \mathrm{l}) \text { : } \\
\text { Mean } \\
\text { SD } \\
\text { Range }\end{array}$ & $\begin{array}{l}7 \cdot 57 \\
5 \cdot 89 \\
1 \cdot 00-25 \cdot 80\end{array}$ & $\begin{array}{l}0.79 \\
0.44 \\
0.20-1.40\end{array}$ \\
\hline $\begin{array}{l}\text { Urinary cadmium ( } \mu \mathrm{g} / \mathrm{g} \text { creatinine): } \\
\text { Mean } \\
\text { SD } \\
\text { Range }\end{array}$ & $\begin{array}{l}1 \cdot 73 \\
3.00 \\
0.05-20.67\end{array}$ & $\begin{array}{l}0.09 \\
0.08 \\
0.02-0.21\end{array}$ \\
\hline
\end{tabular}

gram creatinine; NAG activity was expressed as nmol/ $\mathrm{h} / \mathrm{mg}$ creatinine.

ENVIRONMENTAL MONITORING

The time weighted average concentration of cadmium $\overrightarrow{\mathrm{G}}$ in the air was estimated during normal work betweeno 0930 and 1630 . The concentration on the various production lines ranged from 0.007 to $0.039 \mathrm{mg} / \mathrm{m}^{3} \cdot \overrightarrow{\mathrm{z}}$ This is below the $0.05 \mathrm{mg} / \mathrm{m}^{3}$ recommendation by ACGIH. ${ }^{16}$

\section{Results}

GENERAL DESCRIPTION OF STUDY POPULATION Of the exposed group $29 \%$ were over 40 whereas most of the non-exposed were in the 30 to 39 age group. Most of the exposed group were Malays whereas the $\mathbb{\perp}$ non-exposed were mainly Chinese (table 1).

As expected the blood and urinary cadmium concentrations of the exposed group are much higher than those of the non-exposed group (table 2).

\section{CORRELATION OF BLOOD CADMIUM AND}

MEASURES OF RENAL FUNCTION

Blood and urinary cadmium concentrations had aํํำ correlation coefficient of 0.36 (table 3 ). Of the four measures of renal function, only NAG and $\beta 2 \mathrm{~m}$ correlated well with the blood cadmium concentration $(0.49$ and 0.43 respectively). Urinary cadmium had a poor correlation with urinary $\beta 2 \mathrm{~m}(\mathrm{r}=0.04)$ but was moderately well correlated with urinary NAG $(r==$. 0.35 ). The correlation coefficient between urinary $\tilde{O}^{-}$ NAG and urinary $\beta 2 \mathrm{~m}$ was $\mathbf{0 . 3 7}$.

Table 3 Correlation matrix of blood cadmium with measures of renal function

\begin{tabular}{|c|c|c|c|c|c|c|}
\hline & Blood cadmium & Urinary cadmium & Serum creatinine & Blood urea & $N A G$ & $\beta 2 m$ \\
\hline $\begin{array}{l}\text { Blood cadmium } \\
\text { Urinary cadmium } \\
\text { Serum creatinine } \\
\text { Blood urea } \\
\text { CNAG } \\
\text { B2m }\end{array}$ & $1 \cdot 00$ & $\begin{array}{l}0.36 \\
1.00\end{array}$ & $\begin{array}{r}-0.02 \\
0.01 \\
1.00\end{array}$ & $\begin{array}{l}0.05 \\
0.09 \\
0.07 \\
1.00\end{array}$ & $\begin{array}{r}0.49 \\
0.35 \\
-0.04 \\
0.18 \\
1.00\end{array}$ & $\begin{array}{l}0.43 \\
0.04 \\
0.24 \\
0.08 \\
0.37 \\
1.00\end{array}$ \\
\hline
\end{tabular}


Table 4 Age adjusted measures of renal function of exposed and control groups

\begin{tabular}{|c|c|c|c|c|c|}
\hline & \multicolumn{2}{|c|}{ Exposed group } & \multicolumn{2}{|c|}{ Non-exposed group } & \multirow[b]{2}{*}{ p Value } \\
\hline & Mean & Adj mean* & Mean & Adj mean & \\
\hline $\begin{array}{l}\text { Serum creatinine }(\mathrm{mg} / \mathrm{dl}) \\
\text { Serum urea }(\mathrm{mg} / \mathrm{dl}) \\
\text { Urinary } \beta 2 \mathrm{~m}(\mu \mathrm{g} / \mathrm{g} \text { creatinine }) \\
\text { Urinary } \mathrm{NAG}(\mathrm{nmol} / \mathrm{h} / \mathrm{mg} \text { creatinine })\end{array}$ & $\begin{array}{l}0.92 \\
27 \cdot 06 \\
213 \cdot 2 \\
218 \cdot 4\end{array}$ & $\begin{array}{l}0.92 \\
27 \cdot 00 \\
212 \cdot 1 \\
218 \cdot 3\end{array}$ & $\begin{array}{c}0 \cdot 81 \\
23 \cdot 11 \\
95 \cdot 2 \\
108 \cdot 6\end{array}$ & $\begin{array}{l}0.81 \\
23 \cdot 59 \\
103 \cdot 2 \\
108 \cdot 5\end{array}$ & $\begin{array}{l}0.12 \\
0.32 \\
0.55 \\
0.04\end{array}$ \\
\hline
\end{tabular}

*Adjusted for age using analysis of covariance (ANCOVA).

\section{COMPARISON BETWEEN EXPOSED AND CONTROL} GROUPS

When the age adjusted measures of renal function are compared between exposed and non-exposed groups, each was higher in the exposed group (table 4) but NAG activity showed a statistically significant difference between the groups $(p=0.04)$.

\section{PROPORTION OF WORKERS WITH ABNORMAL}

MEASUREMENTS

Several studies had derived different normals for urinary NAG activity. Most studies in the West, presumably using Caucasian subjects, give an upper normal limit ( \pm 2 SDs) of between 56.0 to 101.5 $\mathrm{nmol} / \mathrm{h} / \mathrm{mg}$ creatinine (table 5 ). An earlier study in Singapore using a similar method of determination gave an upper normal limit of $147.0 \mathrm{nmol} / \mathrm{h} / \mathrm{mg}$ creatinine. ${ }^{12}$ The present study on the nine sedentary staff gave a slightly lower value of $139.0 \mathrm{nmol} / \mathrm{h} / \mathrm{mg}$ creatinine.

Urinary NAG activity detected the largest proportion of abnormalities in the exposed group whichever of the last two upper limits was used (table 6). Furthermore, with increasing blood cadmium concentrations, an increasing proportion of workers had abnormal urinary NAG activity. For exposed workers with a blood cadmium below $5 \mu \mathrm{g} / \mathrm{l}$, more than $50 \%$ had abnormal NAG levels. Only $15.4 \%$ of the exposed workers had abnormal urinary $\beta 2 \mathrm{~m}$ levels, and of these, only one had a normal urinary NAG activity (table 7). Of the exposed workers, 33 had normal urinary $\beta 2 \mathrm{~m}$ but abnormal urinary NAG activity. This difference in distribution is highly significant (Sign test, 2 tailed $\mathrm{p}<0.001) .{ }^{17}$

\section{DOSE RESPONSE RELATION}

With increasing urinary cadmium concentrations, serum creatinine, serum urea, and urinary $\beta 2 \mathrm{~m}$ failed to show any consistent rise (figs 1 and 2). Age adjusted urinary NAG activity showed a statistically significant rise with urinary cadmium concentrations above $3 \mu \mathrm{g} / \mathrm{g}$ creatinine (fig 3 ). Even a urinary cadmium concentration between 1 and $3 \mu \mathrm{g} / \mathrm{g}$ creatinine produced a doubling of the age adjusted urinary NAG activity, although this was just outside the conventional levels of statistical significance $(p=0.055)$.

Table 5 Normal NAG values

\begin{tabular}{|c|c|c|c|}
\hline Source & $\begin{array}{l}\text { Study } \\
\text { population }\end{array}$ & $M e a n \pm S D$ & $\begin{array}{l}\text { Upper limit } \\
(+2 S D s)\end{array}$ \\
\hline $\begin{array}{l}\text { Wellwood et al }{ }^{19} \\
\text { Sherman et al } \\
\text { Tucker et al } \\
\text { 21 } \\
\text { Ong et al }{ }^{12} \\
\text { Present study }\end{array}$ & $\begin{array}{l}8 \text { women } \\
18 \text { subjects } \\
30 \text { subjects } \\
9 \text { women }\end{array}$ & $\begin{array}{l}36 \pm 10 \\
23 \pm 16 \\
57 \cdot 5 \pm 22 \\
87 \pm 30 \\
109 \pm 15\end{array}$ & $\begin{array}{r}56 \cdot 0 \\
55 \cdot 0 \\
101 \cdot 5 \\
147 \cdot 0 \\
139 \cdot 0\end{array}$ \\
\hline
\end{tabular}

Similarly the age adjusted mean serum creatinine and serum urea concentrations failed to show a rise with increasing blood cadmium concentrations (fig 4). Even with blood cadmium concentrations greater than $10 \mu \mathrm{g} / \mathrm{l}$, no significant rise was noted. Urinary $\beta 2 \mathrm{~m}$ concentrations increased only when the blood cadmium was greater than $10 \mu \mathrm{g} / 1$ (fig 5). Urinary NAG, however, showed a doubling with blood cadmium concentrations between 1 and $3 \mu \mathrm{g} / \mathrm{l}$ (fig 6). This is followed by a plateau until the blood cadmium reaches above $10 \mu \mathrm{g} / 1$ when the NAG activity was appreciably raised. The urinary cadmium concentration between this blood range was low (1.17 $\mu \mathrm{g} \mathrm{Cd} / \mathrm{g}$ creatinine).

Table 6 Proportion of workers with abnormal renal function

\begin{tabular}{|c|c|c|c|c|c|c|}
\hline & \multirow{2}{*}{$\begin{array}{l}\text { Non- } \\
\text { exposed }\end{array}$} & \multicolumn{5}{|c|}{ Exposed group, blood cadmium concentrations ( $\mu g / l)$} \\
\hline & & $<3.0$ & $3.0<<5.0$ & $5.0<10.0$ & $\geqslant 10.0$ & Total \\
\hline $\begin{array}{l}\text { No of subjects } \\
\text { Serum urea }(>40 \mathrm{mg} / \mathrm{dl}) \\
\text { Serum creatinine }(>1.3 \mathrm{mg} / \mathrm{dl}) \\
\beta 2 \mathrm{~m}(>200 \mu \mathrm{g} / \mathrm{g} \mathrm{cr}) \\
\text { NAG }(>147)^{*} \\
\text { NAG }(>139) *\end{array}$ & $\begin{array}{l}9 \\
0 \\
0 \\
0 \\
0\end{array}$ & $\begin{array}{l}13 \\
0 \\
0 \\
2(15 \cdot 4) \\
5(38 \cdot 5) \\
6(46 \cdot 2)\end{array}$ & $\begin{array}{l}15 \\
2(13 \cdot 3) \\
0 \\
0 \\
9(60 \cdot 0) \\
9(60.0)\end{array}$ & $\begin{array}{l}24 \\
1(4 \cdot 2) \\
1(4 \cdot 2) \\
3(12 \cdot 5) \\
15(62 \cdot 5) \\
16(66 \cdot 6)\end{array}$ & $\begin{array}{l}13 \\
0 \\
0 \\
5(38 \cdot 5) \\
10(76 \cdot 9) \\
11(84 \cdot 6)\end{array}$ & $\begin{array}{l}65 \\
3(4 \cdot 6) \\
1(1 \cdot 5) \\
10(15 \cdot 4) \\
39(60 \cdot 0) \\
42(64 \cdot 6)\end{array}$ \\
\hline
\end{tabular}

*NAG activity expressed as nmol/h/mg creatinine. 
Table 7 Distribution of workers with abnormal NAG and B2-microglobulin

\begin{tabular}{lcc}
\hline Description & No & $\%$ \\
\hline Normal NAG, normal $\beta 2 \mathrm{~m}$ & 22 & $33 \cdot 8$ \\
Normal NAG, abnormal $\beta 2 \mathrm{~m}$ & 1 & $1.5^{*}$ \\
Abnormal NAG, normal $\beta 2 \mathrm{~m}$ & 33 & $50 \cdot 8^{*}$ \\
Abnormal NAG, abnormal $\beta 2 \mathrm{~m}$ & 9 & 13.9 \\
\hline
\end{tabular}

* Significant difference between the proportion of abnormals using the Sign test (2 tailed).

\section{Discussion}

This study confirms that occupational exposure to cadmium results in renal tubular dysfunction. Among the four measures of renal function studied, NAG and $\beta 2 \mathrm{~m}$ are the most sensitive. Conventional indices of renal function such as total urinary protein, serum urea, and serum creatinine are insensitive indicators of early renal dysfunction (Lauwerys $\mathbf{R}$, Bernard $A$, at 1st Asia Pacific symposium on environmental and occupational toxicology, Singapore 1987) and become abnormal only when there is major impairment of renal excretory function.

Several indices had been suggested as early indicators of renal dysfunction ${ }^{18}$ (and Lauwerys $R$, Bernard A, Ouled A, at XXIInd International Congress of Occupational Health, Sydney 1987). These include the use of renal enzymes, ${ }^{8}$ which the assay of urinary NAG activity had proved to be useful and practical. There appears to be a great disparity between normal values for urinary NAG activity obtained from different studies. ${ }^{12}{ }^{19-21}$ This may be attributed to differences in methods of NAG determination and possibly to racial differences.

The present study suggests that urinary NAG activity is a more sensitive indicator of early renal tubular impairment in workers exposed to cadmium than $\beta 2 \mathrm{~m}$. NAG appears to be raised at lower blood and urinary cadmium concentrations and is capable of detecting more abnormalities among the exposed

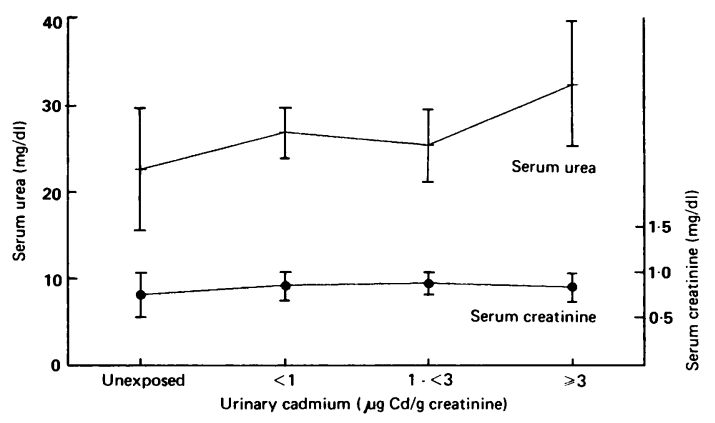

Fig 1 Age adjusted serum urea and serum creatinine by urinary cadmium.

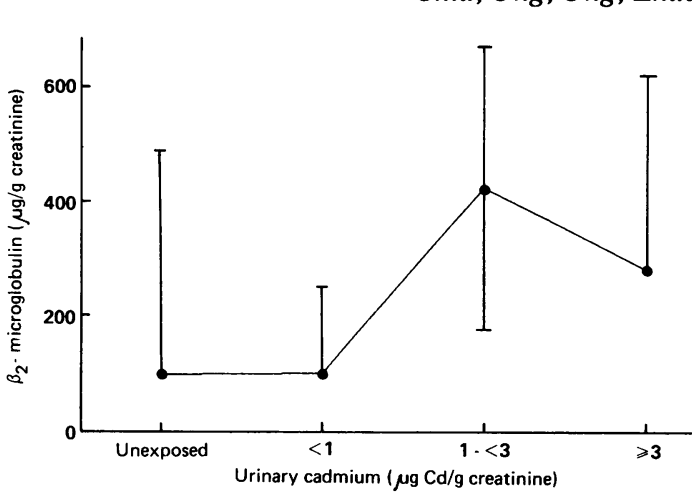

Fig 2 Age adjusted $\beta 2$-microglobulin by urinary cadmium.

workers than $\beta 2 \mathrm{~m}$. Himeno also found NAG to be $\overrightarrow{-}$ more sensitive than $\beta 2 \mathrm{~m}$ and total protein in his studyer on workers exposed to mercury. ${ }^{10}$ This observation is in contrast to a study by Bernard et al in which NAGappeared to be much less frequently raised than $\beta 2 \mathrm{~m}_{\mathrm{D}}$ and retinol binding protein in patients. ${ }^{22}$ Verschoor et al in their recent study among workers exposed to cadmium found a significant relation between urinary $\overrightarrow{0}$ NAG activity and urinary cadmium concentrations. 60 They concluded, however, that urinary $\beta 2 \mathrm{~m}$ appearedo to be more sensitive.

An interesting finding in the present study is the "plateau" effect of urinary NAG activity when bloodo cadmium concentrations reach $3-10 \mu \mathrm{g} / 1$. The amount $\frac{\mathrm{Q}}{\varnothing}$

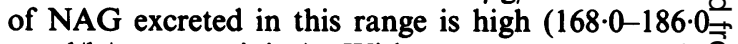
$\mathrm{nmol} / \mathrm{h} / \mathrm{mg}$ creatinine). With acute exposure, the initial high dose of a toxic substance results in an immediate increase in urinary enzyme activity but a second dose fails to provoke an increase. This is possibly due to an extensive loss of tubular cells resulting from the initial dose and because regenerating cells are less susceptible to the toxic agent. ${ }^{823}$ The presence of normal urinary NAG activity among

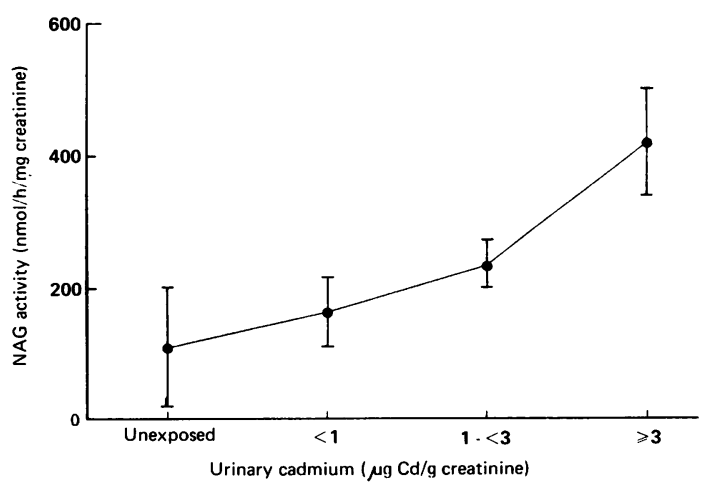

Fig 3 Age adjusted NAG by urinary cadmium. 


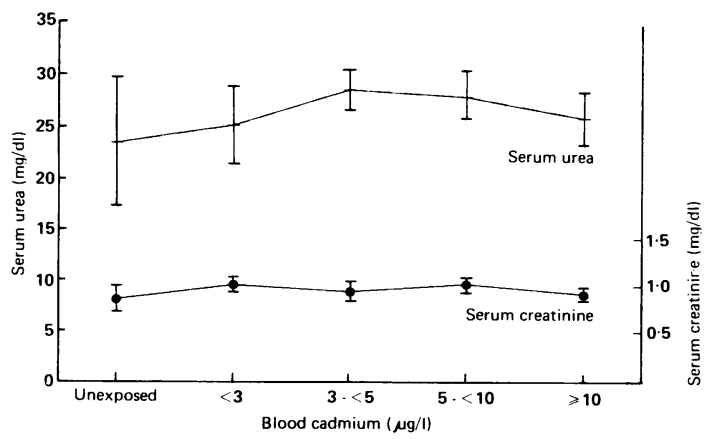

Fig 4 Age adjusted serum urea and serum creatinine by blood cadmium.

workers with high blood lead concentrations has also been explained by these mechanisms.'

In the present study cadmium exposure was low and the initial high and subsequent low urinary enzyme activity seen in animal studies of acute toxic effects would not be expected. The constant NAG activity between 3 and $10 \mu \mathrm{g} / 1$ of cadmium is probably due to a gradual increase in tissue resistance that is keeping pace with the increasing cadmium load. Alternatively, it may indicate that blood cadmium correlates poorly with urinary cadmium at blood concentrations below $10 \mu \mathrm{g} / \mathrm{l}$ and is a poor indicator of the renal cadmium load.

The long term consequence of abnormal measures of renal function (such as $\beta 2 \mathrm{~m}$ ) is the subject of much debate. Such abnormalities are suggestive of early irreversible renal dysfunction (Lauwerys $\mathbf{R}$, Bernard A, Singapore 1987) and a significant excess of deaths from renal disease has been reported among workers with more than 15 years exposure to cadmium. ${ }^{24}$ Abnormalities in the renal handling of protein are to be considered as an adverse effect ${ }^{25}$ and the maximal biological limit of $5 \mu \mathrm{g} \mathrm{Cd} / \mathrm{g}$ creatinine may need to be reviewed. ${ }^{26}$

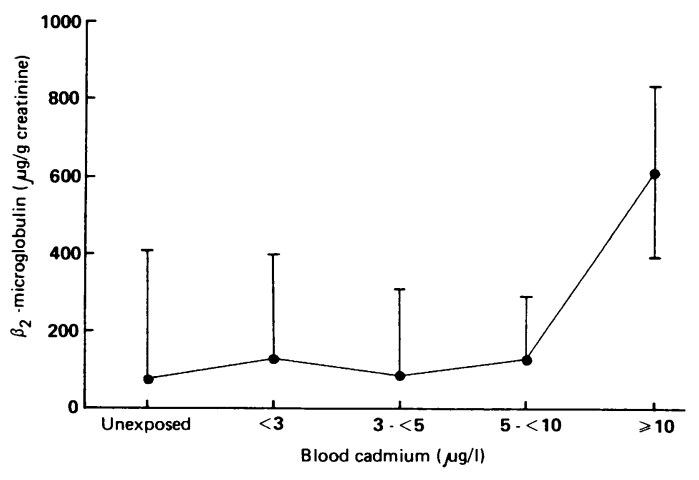

Fig 5 Age adjusted B2-microglobulin by blood cadmium.

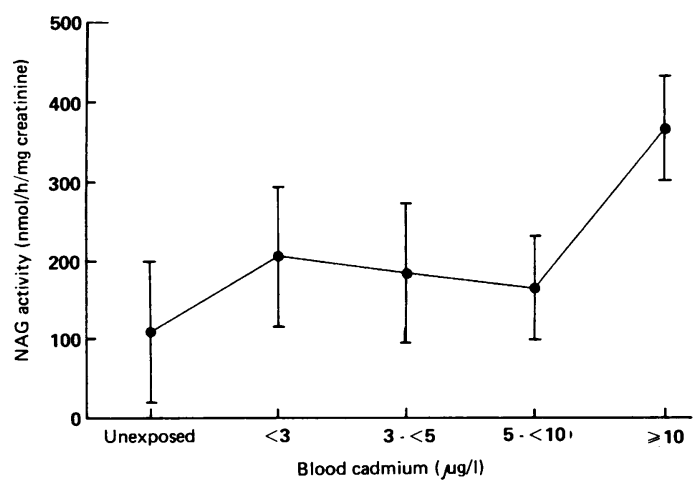

Fig 6 Age adjusted NAG by blood cadmium.

\section{References}

1 Friberg L. Health hazards in the manufacture of alkaline accumulators with special reference to chronic cadmium poisoning. Acta Med Scand 1950;138(suppl 240):1-124.

2 Friberg L. Cadmium and the kidney. Environ Health Perspect 1984;54:1-11.

3 Buche JP, Roels H, Bernard A, Lauwerys R. Assessment of renal function of workers exposed to inorganic lead, cadmium or mercury vapour. J Occup Med 1980;22:741-50.

4 Elinder CG, Edling C, Lindberg E, Kagendal B, Vesterberg O. Assessment of renal function in workers previously exposed to cadmium. $\mathrm{Br} J$ Ind $\mathrm{Med}$ 1985;42:754-60.

5 Elinder CG, Edling C, Lindberg E, Kagendal B, Vesterberg $O$. Beta-2-microglobulinuria among workers previously exposed to cadmium: follow up and dose-response analysis. $\mathrm{Am} \mathrm{J}$ Ind Med 1985;8:553-64.

6 Verschoor M, Herber R, Hermen J, Wibowo A, Zielhuis R. Renal function of workers with low-level cadmium exposure. Scand $J$ Work Environ Health 1987;13:232-8.

7 Buell G. Some biochemical aspects of cadmium toxicology. $J$ Occup Med 1975;17:189-95.

8 Price RG. Urinary enzymes, nephrotoxicity and renal disease. Toxicology 1982;23:99-134.

9 Meyer BR, Rosenman K, Lerman Y, Drayer DE, Reidenberg $M M$. Increased urinary enzyme excretion in workers exposed to nephrotoxic chemicals. Am J Med 1984;76:989-98.

10 Himeno S, Watanabe C, Suzuki T. Urinary biochemical changes in workers exposed to mercury vapour. Ind Health 1986;24:151-5.

11 Rosenman K, Valciukas J, Glickman L, Meyers B, Cinotti A. Sensitive indicators of inorganic mercury toxicity. Arch Environ Health 1986;41:208-15.

12 Ong CN, Endo G, Chia KS, Phoon WO, Ong HY. Evaluation of renal function in workers with low blood lead levels. In: Fao V, Emmett E, Maroni H, Colombi A, eds. Occupational and environmental chemical hazards. W Sussex; Horwood Limited, 1986: 214-21.

13 Phoon WO, Ong CN, Chia KS, et al. Effects of low level lead absorption-a collaborative epidemiological study between Japan and Singapore. International Centre for Medical Research Annals 1985;5:193-206.

14 Evrin PE, Wibell $L$. The serum levels and urinary excretion of 2microglobulin in apparently healthy subjects. Scandinavian Journal of Clinical and Laboratory Investigations 1972;29: 69-74.

15 Noto A, Ogawa Y, Moni S, et al. Simple and rapid spectrophotometry of urinary $\mathrm{N}$-acetyl-D-glucosaminidase with use of a new chromogenic substrate. Clin Chem 1983;29:1713-6.

16 American Conference of Governmental Industrial Hygienists. 
Threshold limit values and biological exposure indices for 19861987. Cincinnati: ACGIH, 1988.

17 Bourke G, Daly L, McGilvray J. Comparison of paired proportions. In: Interpretation and uses of medical statistics. 3rd ed. Oxford: Blackwell Scientific Publications, 1985:122-4.

18 Sakurai $H$. Epidemiologic approach to subclinical effects of metals in long term occupational exposure. In: Holmstedt B, Lauwerys R, Mercier M, Roberfroid R, eds. Mechanisms of toxicity and hazards evaluation. Amsterdam: Elsevier North-Holland Biomedical Press, 1980:293-305.

19 Wellwood J, Ellis B, Price R, Hammond K, Thompson A, Jones N. Urinary $\mathrm{N}$-acetyl-D-glucosaminidase activities in patients with renal disease. $\mathrm{Br}$ Med J 1975; iii:408-11.

20 Sherman R, Drager D, Leyland-Jones B, Reidenberg M. N-acetylD-glucosaminidase and 2-microglobulin-their excretion in patients with renal parenchymal disease. Arch Intern Med 1983;143:1183-5.

21 Tucker S, Boyd P, Thompson A, Price R. Automated assay of N-
acetyl-D-glucosaminidase in normal and pathological human urine. Clin Chim Acta 1975;62:333-9.

22 Bernard A, Maheiu P, Viau C, Lauwerys R. Evaluation of retinol:binding protein, 2-microglobulin, ferritin and $\mathrm{N}$-acetyl-D glucosaminidase as indices of renal tubular damage. In: Bach $\mathrm{P}$ Lock E, eds. Renal heterogeneity and target cell toxicity Chichester: John Wiley, 1985:299-302.

23 Tandon S, Magos L, Cabral J. Protection against mercuriā chloride by nephrotoxic agents which do not induce thionein Toxicol Appl Pharmacol 1980;52:227-36.

24 Kjellstrom T, Fridberg L, Rahnster D. Mortality and cancep morbidity among cadmium exposed workers. Environ Health Perspect 1979;28:199-204.

25 Lauwerys R, Bernard A. Cadmium and the kidney. Br J Ind Med 1986;43:433-5.

26 World Health Organisation study group. Recommended health based limits in occupational exposure to heavy metals. Geneva WHO 1980. (WHO tech rep ser No 647.) 